\title{
Estimating wildfire response costs in Alaska's changing climate
}

\author{
April M. Melvin ${ }^{1} \cdot$ Jessica Murray $^{2} \cdot$ Brent Boehlert $^{2,3}$. \\ Jeremy A. Martinich ${ }^{4} \cdot$ Lisa Rennels $^{2}$ - T. Scott Rupp ${ }^{5}$
}

Received: 19 October 2016 / Accepted: 8 February 2017 / Published online: 24 February 2017

(C) The Author(s) 2017. This article is published with open access at Springerlink.com

\begin{abstract}
Climate change is altering wildfire activity across Alaska, with increased area burned projected for the future. Changes in wildfire are expected to affect the need for management and suppression resources; however, the potential economic implications of these needs have not been evaluated. We projected area burned and associated response costs to 2100 under relatively high and low climate forcing scenarios (representative concentration pathways (RCP) 8.5 and 4.5) using the Alaskan Frame-based Ecosystem Code (ALFRESCO) model. We calculated unique response costs for each of the four fire management options (FMOs) currently used in Alaska that vary in suppression level using federal cost data. Cumulative area burned between 2006 and 2100 across Alaska averaged 46.7M ha under five climate models for RCP8.5 and $42.1 \mathrm{M}$ ha for RCP4.5, with estimated cumulative response costs of \$1.2-2.1B and \$1.1-2.0B, respectively (3\% discount). The largest response costs were incurred for the Full FMO, an area of high suppression priority, but where risks to human life and property are relatively low. Projected response costs across the century indicated that costs would be largest annually in the 2090 era (2080-2099) under RCP8.5, totaling \$41.9-72.9M per year. For RCP4.5, the highest costs were projected for the 2070 era (2060-2079) and totaled \$36.2-63.4M per year. The
\end{abstract}

Electronic supplementary material The online version of this article (doi:10.1007/s10584-017-1923-2) contains supplementary material, which is available to authorized users.

Jeremy A. Martinich

martinich.jeremy@epa.gov

1 AAAS Science \& Technology Policy Fellow hosted by the U.S. Environmental Protection Agency, Climate Change Division, Washington, DC 20460, USA

2 Industrial Economics, Inc., Cambridge, MA 02140, USA

3 Massachusetts Institute of Technology, Joint Program on the Science and Policy of Global Change, Cambridge, MA 02139, USA

4 U.S. Environmental Protection Agency, Climate Change Division, 1200 Pennsylvania Ave. NW, 6207A, Washington, DC 20460, USA

5 International Arctic Research Center, Scenarios Network for Alaska \& Arctic Planning, University of Alaska Fairbanks, Fairbanks, AK 99775, USA 
relative change in annual area burned showed larger increases for RCP8.5 than RCP4.5 across much of the state. The reported response costs are likely an underestimate and limited available data for state incurred costs suggests that realized costs could be $\sim 68 \%$ higher. These findings indicate that climate change will have continued impacts on wildfire response costs across Alaska that vary among FMOs and global greenhouse gas emissions futures.

\section{Introduction}

Climate change has been linked to an increase in wildfire activity across the North American boreal forest (Flannigan et al. 2009a; Gillett et al. 2004; Kasischke et al. 2010; Kelly et al. 2013), with further increases in frequency and extent projected for the future (Balshi et al. 2009; Flannigan et al. 2009b; Flannigan et al. 2016). While this ecosystem is well adapted to fire, increased fire activity can facilitate long-term changes to ecosystem structure and function (Johnstone et al. 2010) and elevate risks to society (Trainor et al. 2009). In Alaska, increased wildfire activity is occurring concurrent with greater human settlement in the wildland-urban interface (WUI), thereby heightening the potential for direct human exposure to fire (Berman et al. 1999; Calef et al. 2008; Cohen 2000) and the need for greater financial resources to suppress wildfire spread.

Alaska's landscape presents unique challenges that have shaped wildfire suppression policies. Boreal forest covers about $60 \%$ of the state (Markon et al. 2012) and is dominated by black spruce (Picea mariana), a highly flammable tree species that has contributed to the burning of hundreds of thousands of hectares annually in recent decades (AICC 2016; Todd and Jewkes 2006). The vast size of the boreal forest and limited road network across Alaska make fire suppression logistically difficult and costly, especially in remote areas, where lightning-caused fires are common (Todd and Jewkes 2006). Wildfire suppression in Alaska formally began 1939 , and in the early years, focus was placed on suppression and prevention of as many fires as possible, despite very limited resources (Todd and Jewkes 2006). Over time, the impracticality of fighting all fires in Alaska, evolving US fire policy, and improved understanding of the ecological importance of fire, contributed to a shift towards wildfire management instead of simply suppression and prevention. In the 1980s, fire management options (FMOs) were introduced and are currently in use by fire agencies in Alaska. Wildfire agencies and landowners designate lands into four FMOs - Critical, Full, Modified, and Limited — which prioritize the allocation of resources and inform unique response protocols (AICC 2016; AIWFMP 2010) (Table 1). Land assignment to an FMO is based on many factors including public and firefighter safety, existing policies, property value, natural and cultural resources, environmental health and sustainability, and potential suppression costs (AIWFMP 2010). Land designation to each FMO is revised annually, to reflect changes in the location of valuable property and in consideration of where fire occurrence many improve habitat for wildlife (Trainor et al. 2009). Because of the uneven distribution of Alaska's population and high-value property, there are considerable differences in location of the total land area within each FMO (see FMO designation map at http://fire.ak.blm.gov/content/maps/aicc/Alaska_Fire_Management Options.pdf). Critical areas receive the highest priority yet comprise the smallest land area (about 1.3 M ha), while Limited areas — where fires are rarely fought — cover the largest portion of the state, totaling over $106 \mathrm{M}$ ha (Table 1).

If projected increases in wildfire activity (Balshi et al. 2009; Flannigan et al. 2009a; Rupp et al. 2016) are realized, the financial resources needed to respond to wildfires are likely to 
Table 1 Characteristics of each FMO in Alaska

\begin{tabular}{llc}
\hline FMO & Characteristics & $\begin{array}{c}\text { Area }^{\text {a }} \\
\text { (thous ands } \\
\text { of ha) }\end{array}$ \\
\hline Critical & $\begin{array}{l}\text { Highest priority areas where the risks to human life, residences, and } \\
\text { community-dependent infrastructure are greatest. All fires are immediately sup- } \\
\text { pressed. }\end{array}$ & 1309 \\
Full & $\begin{array}{l}\text { High-valued areas, but where risks to human life or inhabited property are low. Fires } \\
\text { are usually suppressed. }\end{array}$ & 21,786 \\
Modified & $\begin{array}{l}\text { Areas where risks to humans and infrastructure are relatively low and management } \\
\text { decisions are designed to balance area burned with suppression costs. Suppression } \\
\text { occurs if there is high fire danger. }\end{array}$ & 17,052 \\
Limited & $\begin{array}{l}\text { Typically remote areas with a low density of valuable property, allowing for natural } \\
\text { fire dynamics and associated ecological processes. Not typically suppressed. }\end{array}$ & 106,672 \\
\hline
\end{tabular}

Table descriptions based on AICC 2016

${ }^{a}$ Areas listed for each FMO are those used in this analysis

increase, especially if fires occur in FMOs where suppression is prioritized. We estimated the potential wildfire response costs through 2100 for large $(\geq 100 \mathrm{ha})$ fires within each FMO across Alaska. Further, we considered the benefits (or avoided costs) resulting from global action to reduce greenhouse gas (GHG) emissions. To do this, we projected area burned by wildfire under high and low climate forcing scenarios using the Alaskan Frame-based Ecosystem Code (ALFRESCO) model (Johnstone et al. 2011; Rupp et al. 2007; Rupp et al. 2016; Rupp et al. 2000; Rupp et al. 2002). This model integrates climate, vegetation type, and forest age to calculate a flammability coefficient, which is then used to simulate fire initiation and subsequent spread across the landscape. Wildfire response costs were then calculated based on historic federal expenditure data and spatially-explicit projections of area burned. This study is a new component of a broader, multi-sector modeling framework developed for the Environmental Protection Agency's (EPA) Climate Change Impacts and Risk Analysis (CIRA) project (Martinich et al. 2015), which seeks to estimate the effects of global GHG reductions in avoiding or reducing future impacts and damages.

\section{Methods}

\subsection{Climate projections and model overview}

Future climate was projected using five previously downscaled general circulation models (GCMs) determined to have the most skill for Alaska and the Arctic (Walsh et al. 2008; https://www.snap.uaf.edu/methods/models, detailed in Online Resource 1). Model skill is a criterion to select a subset of GCMs that are able to best re-create historical climate in a region (e.g., see (McSweeney et al. 2015; Rupp et al. 2013; Vano et al. 2015). In the context of the GCMs used in this analysis, skill is measured based on the degree to which each GCM's output aligned with observed climate data from 1958 to 2000 for precipitation, sea level pressure, and surface air temperature. Due to nonstationarity, skill at matching observations may not always lead to superior representation of future climate conditions. Projections for the five GCMs included representative concentration pathways (RCP) 8.5 (high GHG emissions) and RCP4.5 (lower GHG emissions) from the Coupled Model Intercomparison Project Phase 
5 (CMIP5; Taylor et al. 2012), which were selected to be consistent with the forcing scenarios being used in the forthcoming Fourth National Climate Assessment (USGCRP 2015) and availability of data.

Next, the downscaled temperature and precipitation data were input to the ALFRESCO model. ALFRESCO is a spatially-explicit, landscape-scale biogeographic model of vegetation and wildfire dynamics that incorporates climate information to project vegetation distribution and fire regime under future climate conditions. The primary spatial process employed in the model is the stochastic simulation of fire regime, which is carried out at a 100-ha grid cell resolution. Climate, vegetation type, and successional age of each grid cell are used to calculate a flammability coefficient, which is used to simulate fire initiation and subsequent spread across multiple grid cells. Flammability is affected by climate through a weighted function of monthly average temperatures in March through June and monthly precipitation totals in June and July (Johnstone et al. 2011). The function governing the influence of climate on flammability explains $79 \%$ of the variability in logarithm of area burned annually, based on Alaska fire data from 1950 to 2004 (Duffy et al. 2005). Fire spread is based on neighboring pixel flammability and the presence of fire breaks on the landscape (Johnstone et al. 2011). For a more detailed description of the model, see Johnstone et al. 2011, Mann et al. 2012, Rupp et al. 2007, Rupp et al. 2016, Rupp et al. 2000, and Rupp et al. 2002.

We relied on a mode in ALFRESCO that considers the spatial distribution of FMOs and adjusts the probability of fire spread between cells (i.e., fire is less likely to spread in FMOs with higher suppression priority). We conducted 200 replicate simulations for the 1901-2100 time period for each of the $10 \mathrm{GCM} \times \mathrm{RCP}$ combinations. Past experience and testing of ALFRESCO determined that 200 replicates capture the inherent variability of the stochastic fire simulations, and therefore we selected this number for our analysis. Because ALFRESCO is a stochastic model, each replicate simulation produced a different spatial and temporal pattern of wildfire occurrence. We relied on the median value across the 200 simulations for most analyses, which allowed for greater statistical certainty in projected outcomes for each FMO. To illustrate the variation across these simulations, we also report the 25th and 75th percentile values for many of our results. We focused on output of area burned (a yes/no designation for each 100 ha grid cell, calculated on an annual time step) and also evaluated the extent of dominant vegetation types to inform the discussion of results (see Online Resource 1). Projected annual area burned was aggregated by FMO to calculate response costs between RCPs and across four, 20-year eras presented with the central year: 2030 (2020-2039), 2050 (2040-2059), 2070 (2060-2079), and 2090 (2080-2099). Response costs were estimated using the five-model average of the median area burned across the 200 replicate simulations. Projections of annual area burned were compared with modeled historical (1970-2005) fire extent to evaluate the relative change over time. The total area burned for each FMO within this historical baseline period is reported in Online Resource 2, Tables S2 and S4.

\subsection{Wildfire response costs}

The responsibility and incurred costs of responding to wildfires in Alaska are shared by state and federal agencies. At this time, a detailed compilation of historically incurred costs that reflect expenditures of both state and federal sources is not available. Therefore, we used federal cost data that was publicly available as the basis for our study, but also discuss how inclusion of state expenditures could influence our reported response costs. We estimated response costs per hectare burned for each FMO using historical (2002-2013) data from the 
Alaska Interagency Coordination Center (AICC, http://fire.ak.blm.gov/) and the National Fire and Aviation Management web application (http://fam.nwcg.gov/fam-web/hist_209/report list_209) and provide detailed methods in Online Resource 1. These databases included costs reported by federal agencies for fires $\geq 100$ ha in size and fires that required an Incident Management Team Type 1 or 2 response (i.e., high priority suppression requiring a complex response with large resource needs). Only $28 \%$ of reported fires included response costs; however, it is likely that some fires incurred costs that were not reported (AICC, personal communication). We estimated costs per unit area both with and without inclusion of fires with no cost data reported (Table S1). We determined that inclusion of fires with no cost data helps to standardize costs within an FMO and account for the expectation that not all fires or hectares burned will be actively fought, especially in FMOs with low suppression priority. However, because some fires with incurred costs may not have been reported (such as small fires located in high-priority suppression areas), this approach may underestimate the response cost per unit area. We also calculated response cost per unit area using total hectares burned only for fires with reported response costs. This approach may give a more accurate response cost per unit area for fires that are fought; however, it does not account for areas where active suppression measures are not employed. Estimated costs using this approach were higher for all FMOs, as expected; however, there was large variation in the relative difference between the two approaches (Table S1). Future response costs were estimated by applying the FMO-specific cost per hectare to the projected annual area burned within each FMO using both cost estimate approaches, to illustrate a potential range in future costs.

State-incurred costs (including many fires $<100$ ha in size) can make up a large proportion of total annual costs to Alaska that our projected estimates do not capture. For instance, between 2009 and 2015, an average of $68 \%$ ( $\pm 8 \%$ SD) of annual costs were incurred by the state (B. Fronterhouse and K. Herrera, personal communication). This indicates that the cost per hectare values we used in this analysis are likely a considerable underestimate of what will be realized to respond to wildfire in the future. The 2009-2015 data represent total annual costs for a somewhat different time period than we used in cost estimate development and we cannot distinguish among FMOs, determine individual fire sizes, or estimate costs per unit area. Since FMOs and area burned were metrics central to our cost calculations, we are limited in our ability to determine how large an underestimate our projected values represent. However, to acknowledge that our estimates could be $\sim 68 \%$ lower than the combined state and federal costs, we report values that are $68 \%$ higher alongside the costs projected using the federal-only data for some of our results.

\section{Results}

Projected cumulative area burned in Alaska between 2006 and 2100 averaged 46.7M ha across the five GCMs under RCP8.5, and 42.1M ha for RCP4.5 (Table 2). For both RCPs, approximately $67 \%$ of projected area burned occurred in the Limited FMO, while 17 and $15 \%$ of burned area was contained in the Full and Modified FMOs, respectively. Critical areas accounted for $0.5 \%$ of cumulative area burned. Projected area burned was larger for RCP8.5 than RCP4.5 for all FMOs and GCMs except Modified and Limited under one model (MRICGCM3). Mean cumulative response costs (3\% discount, 2015\$) were similar for the two RCPs, averaging \$1.2-2.1B and \$1.1-2.0B for RCP8.5 and RCP4.5, respectively, where the range represents the mean based on all reported wildfires (lower value) and only fires with 
Table 2 Cumulative area burned for each of the five GCMs and two RCPs for the 2006-2100 time period, reported for the entire state and each FMO

\begin{tabular}{|c|c|c|c|c|c|}
\hline & \multirow{2}{*}{$\begin{array}{l}\text { Statewide } \\
\text { Total }\end{array}$} & \multicolumn{4}{|l|}{ FMO } \\
\hline & & Critical & Full & Modified & Limited \\
\hline \multicolumn{6}{|c|}{ Hectares burned (thousands of ha) } \\
\hline \multicolumn{6}{|l|}{ RCP8.5 } \\
\hline CCSM4 & $\begin{array}{l}53,580 \\
(38,113,59,512)\end{array}$ & 291 & 9099 & 8115 & 36,074 \\
\hline GFDL-CM3 & $\begin{array}{l}50,548 \\
(39,059,62,543)\end{array}$ & 282 & 8833 & 7596 & 33,838 \\
\hline GISS-E2-R & $\begin{array}{l}42,484 \\
(27,304,47,227)\end{array}$ & 230 & 7098 & 6560 & 28,597 \\
\hline IPSL-CM5-LR & $\begin{array}{l}51,980 \\
(35,472,59,320)\end{array}$ & 275 & 8700 & 7794 & 35,211 \\
\hline MRI-CGCM3 & $\begin{array}{l}35,142 \\
(30,251,48,087)\end{array}$ & 200 & 6664 & 5307 & 22,971 \\
\hline Ensemble mean & $\begin{array}{l}46,747 \\
(12,432,54,701)\end{array}$ & $\begin{array}{l}255 \\
(23,536)\end{array}$ & $\begin{array}{l}8079 \\
(1864,10,085)\end{array}$ & $\begin{array}{l}7074 \\
(1277,8708)\end{array}$ & $\begin{array}{l}31,338 \\
(7394,35,775)\end{array}$ \\
\hline \multicolumn{6}{|l|}{ RCP4.5 } \\
\hline CCSM4 & $\begin{array}{l}46,233 \\
(43,900,68,442)\end{array}$ & 265 & 7822 & 7001 & 31,145 \\
\hline GFDL-CM3 & $\begin{array}{l}47,988 \\
(41,272,65,773)\end{array}$ & 248 & 8293 & 7419 & 32,028 \\
\hline GISS-E2-R & $\begin{array}{l}34,750 \\
(33,778,56,729)\end{array}$ & 190 & 5996 & 5200 & 23,364 \\
\hline IPSL-CM5-LR & $\begin{array}{l}44,785 \\
(41,571,68,517)\end{array}$ & 235 & 7582 & 6809 & 30,158 \\
\hline MRI-CGCM3 & $\begin{array}{l}36,874 \\
(28,145,46,534)\end{array}$ & 194 & 6158 & 5657 & 24,865 \\
\hline Ensemble mean & $\begin{array}{l}42,126 \\
(14,854,64,092)\end{array}$ & $\begin{array}{l}226 \\
(30,605)\end{array}$ & $\begin{array}{l}7170 \\
(2305,11,533)\end{array}$ & $\begin{array}{l}6417 \\
(1602,10,195)\end{array}$ & $\begin{array}{l}28,312 \\
(8867,41,730)\end{array}$ \\
\hline
\end{tabular}

Values represent the median value across the 200 replicate simulations for each GCM $\times$ RCP combination. The 25 th and 75 th percentile values are shown for select measurements in the format (25th percentile, 75 th percentile)

reported costs (higher value) (Table 3). Further, if we assume that our projections capture only about $32 \%$ of the total costs, as is suggested by the limited State cost data available, then our projected values would increase to approximately \$2.0-3.5B and \$1.8-3.4B. Among FMOs, mean costs were highest for Full and lowest for Critical for both RCPs (Table 3). However, CCSM4 projected higher response costs for RCP4.5 than RCP8.5 for all FMOs, and a similar pattern was observed for MRI-CGCM3 for all FMOs except Critical. Generally among GCMs, both total and FMO-specific response costs were lowest under the GISS-E2-R and MRICGCM3 models under both RCPs.

Total mean annual response costs (undiscounted) varied across eras and between RCPs, but generally increased over time (Fig. 1a). Response costs were consistently higher for the dataset that included only wildfires where response costs were reported (Fig. 1). In the 2030 era, annual costs were projected at $\$ 23.3-40.9 \mathrm{M}$ and $26.9-46.7 \mathrm{M}$ per year for RCPs 8.5 and 4.5, respectively, where the range represents the means based on all reported wildfires (solid bars) and only fires with reported costs (hashed bars). By 2090 , annual costs were projected to increase to $\$ 41.9-72.9 \mathrm{M}$ and $33.8-59.2 \mathrm{M}$ per year. For comparison, mean annual incurred costs for the 2002-2013 historical period were $\$ 31 \mathrm{M}$ per year, suggesting that future costs, particularly late in the century, are likely to 
Table 3 Estimated wildfire response costs for each of the five GCMs and two RCPs for the 2006-2100 time period, reported for the entire state and each FMO, and for costs per unit area calculated from all wildfires and for only those fires reporting costs

\begin{tabular}{|c|c|c|c|c|c|}
\hline & \multirow{2}{*}{$\begin{array}{l}\text { Statewide } \\
\text { Total }\end{array}$} & \multicolumn{4}{|l|}{ FMO } \\
\hline & & Critical & Full & Modified & Limited \\
\hline \multicolumn{6}{|c|}{ Response cost based on costs from all fires (millions of USD, 2015\$) } \\
\hline \multicolumn{6}{|c|}{ RCP8.5 } \\
\hline CCSM4 & $\begin{array}{l}\$ 1309 \\
(\$ 889, \$ 1869)\end{array}$ & $\$ 53$ & $\$ 843$ & $\$ 182$ & $\$ 231$ \\
\hline GFDL-CM3 & $\begin{array}{l}\$ 1497 \\
(\$ 1039, \$ 2128)\end{array}$ & $\$ 57$ & $\$ 993$ & $\$ 199$ & $\$ 249$ \\
\hline GISS-E2-R & $\begin{array}{l}\$ 886 \\
(\$ 562, \$ 1363)\end{array}$ & $\$ 36$ & $\$ 566$ & $\$ 125$ & $\$ 159$ \\
\hline IPSL-CM5-LR & $\begin{array}{l}\$ 1459 \\
(\$ 972, \$ 2133)\end{array}$ & $\$ 53$ & $\$ 940$ & $\$ 207$ & $\$ 259$ \\
\hline MRI-CGCM3 & $\begin{array}{l}\$ 807 \\
(\$ 518, \$ 1220)\end{array}$ & $\$ 32$ & $\$ 539$ & $\$ 105$ & $\$ 131$ \\
\hline Ensemble mean & $\begin{array}{l}\$ 1192 \\
(\$ 270, \$ 1653)\end{array}$ & $\begin{array}{l}\$ 46 \\
(\$ 4, \$ 112)\end{array}$ & $\begin{array}{l}\$ 776 \\
(\$ 186, \$ 1066)\end{array}$ & $\begin{array}{l}\$ 163 \\
(\$ 30, \$ 220)\end{array}$ & $\begin{array}{l}\$ 206 \\
(\$ 50, \$ 255)\end{array}$ \\
\hline \multicolumn{6}{|l|}{ RCP4.5 } \\
\hline CCSM4 & $\begin{array}{l}\$ 1404 \\
(\$ 972, \$ 1995)\end{array}$ & $\$ 57$ & $\$ 898$ & $\$ 204$ & $\$ 245$ \\
\hline GFDL-CM3 & $\begin{array}{l}\$ 1348 \\
(\$ 907, \$ 1972)\end{array}$ & $\$ 49$ & $\$ 891$ & $\$ 181$ & $\$ 227$ \\
\hline GISS-E2-R & $\begin{array}{l}\$ 750 \\
(\$ 460, \$ 1191)\end{array}$ & $\$ 32$ & $\$ 487$ & $\$ 101$ & $\$ 130$ \\
\hline IPSL-CM5-LR & $\begin{array}{l}\$ 1366 \\
(\$ 920, \$ 1985)\end{array}$ & $\$ 50$ & $\$ 902$ & $\$ 178$ & $\$ 236$ \\
\hline MRI-CGCM3 & $\begin{array}{l}\$ 864 \\
(\$ 569, \$ 1298)\end{array}$ & $\$ 31$ & $\$ 567$ & $\$ 117$ & $\$ 149$ \\
\hline Ensemble mean & $\begin{array}{l}\$ 1146 \\
(\$ 245, \$ 1524)\end{array}$ & $\begin{array}{l}\$ 44 \\
(\$ 4, \$ 104)\end{array}$ & $\begin{array}{l}\$ 749 \\
(\$ 166, \$ 986)\end{array}$ & $\begin{array}{l}\$ 156 \\
(\$ 28, \$ 201)\end{array}$ & $\begin{array}{l}\$ 197 \\
(\$ 48, \$ 233)\end{array}$ \\
\hline \multicolumn{6}{|c|}{ Response cost based on costs from fires with reported costs only (millions of USD, 2015\$) } \\
\hline CCSM4 & $\begin{array}{l}\$ 2303 \\
(\$ 1592, \$ 3235)\end{array}$ & $\$ 54$ & $\$ 1236$ & $\$ 426$ & $\$ 587$ \\
\hline GFDL-CM3 & $\begin{array}{l}\$ 2612 \\
(\$ 1838, \$ 3659)\end{array}$ & $\$ 59$ & $\$ 1456$ & $\$ 465$ & $\$ 633$ \\
\hline GISS-E2-R & $\begin{array}{l}\$ 1563 \\
(\$ 1009, \$ 2358)\end{array}$ & $\$ 37$ & $\$ 830$ & $\$ 293$ & $\$ 403$ \\
\hline IPSL-CM5-LR & $\begin{array}{l}\$ 2577 \\
(\$ 1743, \$ 3707)\end{array}$ & $\$ 54$ & $\$ 1379$ & $\$ 484$ & $\$ 660$ \\
\hline MRI-CGCM3 & $\begin{array}{l}\$ 1402 \\
(\$ 916, \$ 2080)\end{array}$ & $\$ 33$ & $\$ 790$ & $\$ 245$ & $\$ 334$ \\
\hline Ensemble mean & $\begin{array}{l}\$ 2091 \\
(\$ 475, \$ 2841)\end{array}$ & $\begin{array}{l}\$ 47 \\
(\$ 4, \$ 114)\end{array}$ & $\begin{array}{l}\$ 1138 \\
(\$ 273, \$ 1564)\end{array}$ & $\begin{array}{l}\$ 383 \\
(\$ 71, \$ 515)\end{array}$ & $\begin{array}{l}\$ 523 \\
(\$ 127, \$ 648)\end{array}$ \\
\hline \multicolumn{6}{|l|}{ RCP4.5 } \\
\hline CCSM4 & $\begin{array}{l}\$ 2475 \\
(\$ 1744, \$ 3460)\end{array}$ & $\$ 58$ & $\$ 1316$ & $\$ 477$ & $\$ 624$ \\
\hline GFDL-CM3 & $\begin{array}{l}\$ 2358 \\
(\$ 1608, \$ 3394)\end{array}$ & $\$ 50$ & $\$ 1,307$ & $\$ 424$ & $\$ 578$ \\
\hline GISS-E2-R & $\begin{array}{l}\$ 1314 \\
(\$ 820, \$ 2045)\end{array}$ & $\$ 33$ & $\$ 714$ & $\$ 237$ & $\$ 331$ \\
\hline IPSL-CM5-LR & $\begin{array}{l}\$ 2391 \\
(\$ 1628, \$ 3426)\end{array}$ & $\$ 51$ & $\$ 1323$ & $\$ 417$ & $\$ 600$ \\
\hline MRI-CGCM3 & $\begin{array}{l}\$ 1515 \\
(\$ 1015, \$ 2234)\end{array}$ & $\$ 32$ & $\$ 831$ & $\$ 273$ & $\$ 378$ \\
\hline Ensemble mean & $\begin{array}{l}\$ 2011 \\
(\$ 434, \$ 2616)\end{array}$ & $\begin{array}{l}\$ 45 \\
(\$ 4, \$ 106)\end{array}$ & $\begin{array}{l}\$ 1098 \\
(\$ 243, \$ 1446)\end{array}$ & $\begin{array}{l}\$ 366 \\
(\$ 65, \$ 471)\end{array}$ & $\begin{array}{l}\$ 502 \\
(\$ 122, \$ 592)\end{array}$ \\
\hline
\end{tabular}

Values represent the median value across the two hundred replicate simulations for each GCM $\times$ RCP combination. The 25th and 75th percentile values are shown for select measurements in the format (25th percentile, 75 th percentile) 


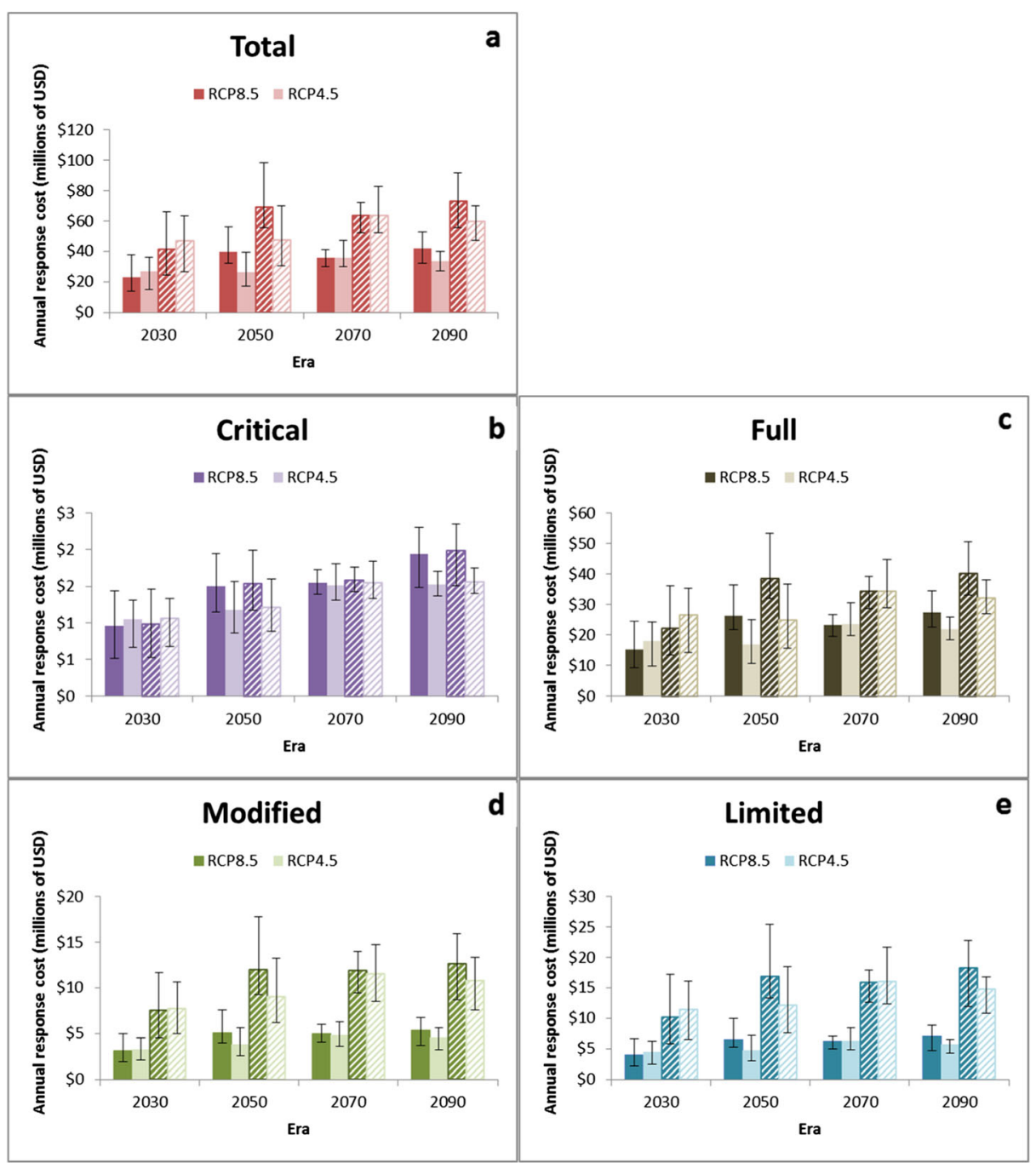

Fig. 1 Projected annual response costs (millions of USD, 2015\$ undiscounted) summed for all FMOs (a) and each FMO individually (Critical, b; Full, c; Modified, d; Limited, e), for each of the RCPs and study eras. Solid bars indicate projections where cost per hectare values include all reported wildfires and hashed bars represent cost per hectare values calculated using only fires that reported response costs. Costs represent the mean of the five GCMs (calculated using the median of 200 replicate simulations for each GCM $\times \mathrm{RCP} \times \mathrm{FMO}$ combination) and error bars illustrate the minimum and maximum GCM values. Note the difference in scale among panels

be higher than those incurred in the recent past. Inclusion of potential state-incurred annual costs that assume $68 \%$ higher costs than those projected would yield estimates of $\$ 39.1-68.7 \mathrm{M}$ and $45.2-78.5 \mathrm{M}$ per year in 2030 for RCP8.5 and RCP4.5, respectively, and $\$ 70.4-122.5 \mathrm{M}$ and $56.8-99.5 \mathrm{M}$ per year in the 2090 era. The highest estimated costs (not accounting for potential state-incurred expenses) were observed for RCP8.5 in the 2050 and 2090 eras, although variability among GCMs was observed across all eras. The relative difference between RCPs was also largest for the 2050 and 2090 eras. Response costs in 2030 were slightly higher for RCP4.5, and in 2070 very little difference was 
observed between RCPs. The FMOs showed similar patterns in relative differences between RCPs within each era; however, the annual response costs varied considerably across FMOs (Fig. 1b-e). The Full FMO exhibited higher response costs than all other FMOs for both RCPs across all eras (Fig. 1c). The highest response costs were projected for the Full FMO under RCP8.5 in the 2050 and 2090 eras, where costs were estimated to be $\$ 26.4-38.7 \mathrm{M}$ and $\$ 27.4-40.2 \mathrm{M}$ annually, respectively. The largest difference between RCPs within an FMO was also observed for the Full FMO in the 2050 era, where annual projected costs were about $\$ 9.4-13.8 \mathrm{M}$ higher for RCP8.5 than RCP4.5 (Fig. 1c).

The relative change in mean annual hectares burned between the historic baseline (1970-2005) and projected 2050 and 2090 eras indicated a larger increase in area burned under RCP8.5 than RCP4.5 across much of the state, especially in 2050 (Fig. 2). The largest increase in area burned for RCP8.5 was observed in the Southwest and Interior, while RCP4.5 projected a smaller increase in the western portion of the state and a decline in hectares burned across much of the Interior. In the 2090 era, the RCPs showed similar patterns in the spatial extent of grid cells projected to burn as compared with the historic baseline, but the increase in projected area burned was larger for RCP8.5 than RCP4.5. Generally, the easternmost part of the state showed a decrease and the North Slope showed a slight increase in area burned for both RCPs and eras (Fig. 2). Statewide, projected decadal area burned generally indicated an increase in area burned late in the century relative to the historic baseline, but variability was observed across GCMs (see Online Resource 2, Tables S2 and S4).

2050

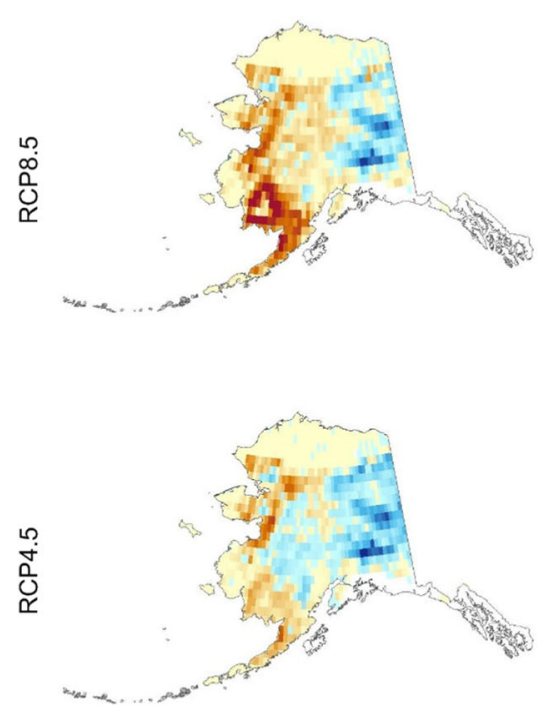

2090

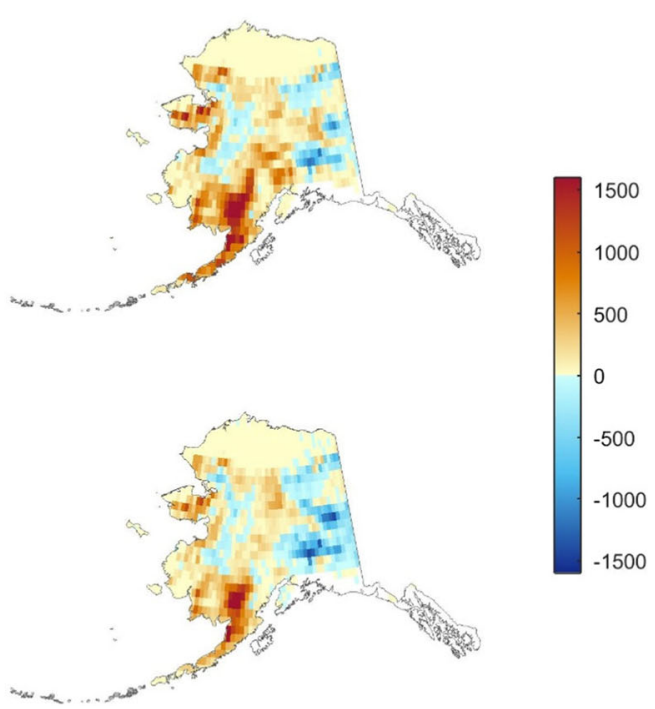

Fig. 2 Relative change in mean annual hectares burned between the baseline period (1970-2005) and the 2050 and 2090 eras for each RCP. Values represent the mean of the five GCMs (calculated using the mean of 200 replicate simulations for each GCM $\times$ RCP combination), illustrated at the $0.5^{\circ} \times 0.5^{\circ}$ grid cell resolution. Positive values reflect a projected increase in mean area burned while negative values indicate locations where mean area burned is projected to decrease relative to the baseline period. White areas represent locations where no change from baseline was projected 


\section{Discussion}

Climate change in Alaska is projected to increase area burned and associated response costs, with potential costs estimated to be \$1.1-2.1B from 2006 through the end of the century.

Area burned and associated response costs were generally larger for RCP8.5 than RCP4.5, indicating that reducing global GHG emissions could modestly lessen the total economic impact of climate change. The difference in area burned this century averaged $4.6 \mathrm{M}$ ha between RCPs, which is a $\sim 10 \%$ reduction in area burned and comparable to the total hectares burned in just 2004 and 2005, two of Alaska's large fire years (AICC 2016). Cumulative response costs differed by about $\$ 46-80 \mathrm{M}$ between RCPs, representing a $\sim 4 \%$ reduction in costs, if the RCP4.5 emissions scenario is realized. The relatively modest benefit of GHG emissions reductions observed here is consistent with a similar analysis for the contiguous USA, which reported a 13-14\% reduction in area burned when comparing high and low GHG emissions futures (CIRA 2015; Mills et al. 2015).

Differences in response costs across the FMOs were influenced by the size of each FMO, the projected area burned, and the response cost per unit area. While the Limited FMO covers the largest area and contained over half the projected cumulative hectares burned, this FMO accounted for only about $17-25 \%$ of the projected incurred costs due to the low response cost per hectare (\$17-44, Table S1). In contrast, the Full FMO (with a \$259-379 per hectare response cost) accounted for only $17 \%$ of the cumulative area burned, but about $54-65 \%$ of incurred costs. Southwest Alaska contains a large area designated as Full and showed the largest projected relative increase in burning (Fig. 2), likely driving this finding.

Total mean annual response costs reported here suggest that Alaska will face a continued and increasing financial burden from wildfires. A similar trend was reported recently for Canada, where a rise in projected area burned resulted in higher suppression costs under RCP8.5 relative to RCP2.6, a lower emission scenario than RCP4.5 (Hope et al. 2016). An increase in wildfire response costs have also been observed in Canada since the 1970s and are expected to continue to grow as a result of climate change and societal factors (Stocks and Martell 2016). In the 2002-2013 historical time period, our annual response costs averaged \$31M per year (AICC 2016). Our projections, which likely substantially underestimate total costs for the reasons discussed below, indicate that this amount could be surpassed by the 2030 era for both RCPs. For all FMOs, the projected decadal area burned was larger in 2050 and 2090 than in 2070 (Tables S2 and S3 in Online Resource 2), which drove the observed pattern in mean annual response costs (Fig. 1). This shift in burning over time was likely influenced by changes in vegetation composition (Figs. S1 and S2 in Online Resource 3), where an observed pattern of increasing deciduous forest dominance (which is less flammable than spruce) reduced area burned and influenced the fire return interval in ALFRESCO (Rupp et al. 2007). Additionally, most of Alaska is projected to experience increased precipitation and the entire state is projected to experience increased temperatures through 2100 across the climate models used here. These climatic factors directly affect fire initiation and subsequent spread in the ALFRESCO model by influencing the flammability of each grid cell (Johnstone et al. 2011). The observed changes among these factors support our observed differences between models in the temporal pattern of decadal area burned (see Tables S2 and S3). The decrease in 2030 relative to the baseline for three of the five GCMs, for example, likely results from a large increase in precipitation during that era, with a less pronounced increase in temperature.

Our response cost estimates would be improved by the use of historical cost per hectare data that includes both state and federally incurred costs. Because we derived per hectare costs using only federal expenditures data, we are likely missing a considerable contribution of costs that are 
incurred by the state for two reasons. First, there are likely instances where both state and federal resources are expended in fighting the same fires. The inclusion of those state expenditures in the per-fire cost reporting would increase the per hectare values. Second, many state response efforts are focused in higher priority management areas, which increases the effort expended. These limitations are clearly illustrated by reported state-incurred costs that accounted for $68 \%$ of total wildfire response costs in Alaska in recent years. When we integrate this finding with our cost estimates, cumulative costs this century rise considerably to $\$ 2.0-3.5 \mathrm{~B}$ and $\$ 1.8-3.4 \mathrm{~B}$, for RCP8.5 and RCP4.5, respectively. This suggests realized costs in the future may be much higher than those reported here, which will likely place an even greater financial burden on fire management agencies. Our estimates could also be improved by evaluation of fixed versus variable costs and how they may change over time in response to wildfire activity.

Enhanced capabilities to project small wildfires and monetize associated response costs would also improve projected cost estimates. Historically, a large proportion of ignited fires have remained smaller than the 100-ha grid cell resolution of the ALFRESCO model (DeWilde and Chapin 2006). This suggests that our approach may be unable to capture many fires. Additionally, many of these small fires have historically occurred within the Critical and Full FMOs (AIWFMP 2010; DeWilde and Chapin 2006), and therefore likely incurred relatively high costs. Another consideration outside the scope of this analysis is the effect of continued expansion of human settlement in the WUI. This could increase the number of human-ignited fires (Calef et al. 2008) and the size of the area designated to higher suppression FMOs. Finally, recent research indicates that climate warming may increase lightning strikes (Romps et al. 2014), which could influence the frequency of lightning-caused fires in the future, provided that increases in precipitation do not serve to counteract these effects.

This study provides a first estimate of potential wildfire response costs for Alaska through the end of the century. Relative differences in area burned among FMOs and the associated response costs presented here may help to inform future resource needs and considerations when balancing societal risks and funding constraints. Future analyses that build on this work would further improve our ability to project changes in wildfire and suppression needs as the climate continues to change.

Acknowledgements We acknowledge the financial support of the U.S. EPA's Climate Change Division (contract \#EP-D-14-031) and thank two anonymous reviewers for comments that improved this manuscript. The views expressed here are those of the authors, and do not necessarily reflect those of the EPA.Authors' contributions A.M.M., J.M., B.B. and J.A.M. developed the study concept and methodology; A.M.M. compiled and calculated response cost estimates; J.M., B.B., L.R., and T.S.R. performed the technical modeling analyses and summarized results; and A.M.M. wrote the paper, with input on technical methods from all authors.

Open Access This article is distributed under the terms of the Creative Commons Attribution 4.0 International License (http://creativecommons.org/licenses/by/4.0/), which permits unrestricted use, distribution, and reproduction in any medium, provided you give appropriate credit to the original author(s) and the source, provide a link to the Creative Commons license, and indicate if changes were made.

\section{References}

AICC (2016) Alaska Interagency Coordination Center

AIWFMP (2010) Alaska Interagency Wildland Fire Management Plan 2010. Alaska Department of Natural Resources, Division of Forestry

Balshi MS, McGuirez AD, Duffy P, Flannigan M, Walsh J, Melillo J (2009) Assessing the response of area burned to changing climate in western boreal North America using a Multivariate Adaptive Regression Splines (MARS) approach. Glob Chang Biol 15:578-600 
Berman M, Juday GP, Burnside R (1999) Climate change and Alaska's forests: people, problems, and policies. In: Weller G, Anderseon PA (eds) Assessing the consequences of climate change for Alaska and the Bering Sea Region, vol 1998, Proceedings of a Workshop at the University of Fairbanks, 29-30 October. University of Alaska Fairbanks, Center for Global Change and Arctic System Research, pp 21-42

Calef MP, McGuire AD, Chapin FS III (2008) Human influences on wildfire in Alaska from 1988 through 2005: an analysis of the spatial patterns of human impacts. Earth Interact 12

CIRA (2015) Climate change in the United States: benefits of global action, 2015. United States Environmental Protection Agency

Cohen JD (2000) Preventing disaster-home ignitability in the wildland-urban interface. J For 98:15-21

DeWilde L, Chapin FS (2006) Human impacts on the fire regime of interior Alaska: interactions among fuels, ignition sources, and fire suppression. Ecosystems 9:1342-1353

Duffy PA, Walsh JE, Graham JM, Mann DH, Rupp TS (2005) Impacts of large-scale atmospheric-ocean variability on Alaskan fire season severity. Ecol Appl 15:1317-1330

Flannigan M, Stocks B, Turetsky M, Wotton M (2009a) Impacts of climate change on fire activity and fire management in the circumboreal forest. Glob Chang Biol 15:549-560

Flannigan MD, Krawchuk MA, de Groot WJ, Wotton BM, Gowman LM (2009b) Implications of changing climate for global wildland fire. Int J Wildland Fire 18:483-507

Flannigan MD, Wotton BM, Marshall GA, de Groot WJ, Johnston J, Jurko N, Cantin AS (2016) Fuel moisture sensitivity to temperature and precipitation: climate change implications. Clim Chang 134:59-71

Gillett NP, Weaver AJ, Zwiers FW, Flannigan MD (2004) Detecting the effect of climate change on Canadian forest fires. Geophys Res Lett 31:4

Hope ES, McKenney DW, Pedlar JH, Stocks BJ, Gauthier S (2016) Wildfire suppression costs for Canada under a changing climate. PLoS One 11:e0157425

Johnstone JF, Hollingsworth TN, Chapin FS III, Mack MC (2010) Changes in fire regime break the legacy lock on successional trajectories in Alaskan boreal forest. Glob Chang Biol 16:1281-1295

Johnstone JF, Rupp TS, Olson M, Verbyla D (2011) Modeling impacts of fire severity on successional trajectories and future fire behavior in Alaskan boreal forests. Landsc Ecol 26:487-500

Kasischke ES, Verbyla DL, Rupp TS, McGuire AD, Murphy KA, Jandt R, Barnes JL, Hoy EE, Duffy PA, Calef M, Turetsky MR (2010) Alaska's changing fire regime-implications for the vulnerability of its boreal forests. Can J For Res 40:1313-1324

Kelly R, Chipman ML, Higuera PE, Stefanova I, Brubaker LB, Hu FS (2013) Recent burning of boreal forests exceeds fire regime limits of the past 10,000 years. Proc Natl Acad Sci U S A 110:13055-13060

Mann DH, Rupp TS, Olson MA, Duffy PA (2012) Is Alaska's boreal forest now crossing a major ecological threshold? Arct Antarct Alp Res 44:319-331

Markon CJ, Trainor SF, Chapin FSI (eds) (2012) The United States National Climate Assessment-Alaska Technical Regional Report: U.S. Geological Survey Circular 1379., p 148

Martinich J, Reilly J, Waldhoff S, Sarofim M, McFarland J (eds) (2015) Special issue on a mutli-model framework to achieve consistent evaluation of climate change impacts in the United States., pp 1-181

McSweeney CF, Jones RG, Lee RW, Rowell DP (2015) Selecting CMIP5 GCMs for downscaling over multiple regions. Clim Dyn 44:3237-3260

Mills D, Jones R, Carney K, St Juliana A, Ready R, Crimmins A, Martinich J, Shouse K, DeAngelo B, Monier E (2015) Quantifying and monetizing potential climate change policy impacts on terrestrial ecosystem carbon storage and wildfires in the United States. Clim Chang 131:163-178

Romps DM, Seeley JT, Vollaro D, Molinari J (2014) Projected increase in lightning strikes in the United States due to global warming. Science 346:851-854

Rupp TS, Starfield AM, Chapin FS (2000) A frame-based spatially explicit model of subarctic vegetation response to climatic change: comparison with a point model. Landsc Ecol 15:383-400

Rupp TS, Starfield AM, Chapin FS, Duffy P (2002) Modeling the impact of black spruce on the fire regime of Alaskan boreal forest. Clim Chang 55:213-233

Rupp TS, Chen X, Olson M, McGuire AD (2007) Sensitivity of simulated boreal fire dynamics to uncertainties in climate drivers. Earth Interact 11:21

Rupp DE, Abatzoglou JT, Hegewisch KC, Mote PW (2013) Evaluation of CMIP5 20th century climate simulations for the Pacific Northwest USA. J Geophys Res-Atmos 118:10884-10906

Rupp TS, Duffy P, Leonawicz M, Lindgren M, Breen A, Kurkowski T, Floyd A, Bennett A, Krutikov L (2016) Climate simulations, land cover, and wildfire. In: Zhu Z, McGuire AD (eds) Baseline and projected future carbon storage and greenhouse-gas fluxes in ecosystems of Alaska. U.S. Geological Survey Professional Paper 1826., p 196

Stocks BJ, Martell DL (2016) Forest fire management expenditures in Canada: 1970-2013. For Chron 92:298-306

Taylor KE, Stouffer RJ, Meehl GA (2012) An overview of CMIP5 and the experiment design. Bull Am Meteorol Soc 93:485-498 
Todd SK, Jewkes HA (2006) Wildland fire in Alaska: a history of organized fire suppression and management in the Last Frontier. University of Alaska Fairbanks, Agricultural and Forestry Experiment Station Bulletin No. 114

Trainor SF, Calef M, Natcher D, Chapin FS, McGuire AD, Huntington O, Duffy P, Rupp TS, DeWilde L, Kwart M, Fresco N, Lovecraft AL (2009) Vulnerability and adaptation to climate-related fire impacts in rural and urban interior Alaska. Polar Res 28:100-118

USGCRP (2015) General decisions regarding climate-related scenarios for framing the fourth national climate assessment, developed by the U.S. Global Change Research Program Scenarios and Interpretive Science Coordinating Group

Vano JA, Kim JB, Rupp DE, Mote PW (2015) Selecting climate change scenarios using impact-relevant sensitivities. Geophys Res Lett 42:5516-5525

Walsh JE, Chapman WL, Romanovsky V, Christensen JH, Stendel M (2008) Global climate model performance over Alaska and Greenland. J Clim 21:6156-6174 